\title{
Isomorphic Learning Model Based on the Qur'an in Early Childhood
}

\author{
Made Saihu ${ }^{1}$
}

DOI: $10.35445 /$ alishlah.v13i2.630

\section{Article Info}

Keywords:

Isomorphic;

Early childhood;

Qur'an;

Home Visit;

Educational Partners;

Upgrading

Kata kunci:

Isomorfis;

Anak Usia Dini;

Al-Qur'an;

Kunjungan Rumah;

Mitra Pendidikan;

Penataran

\section{Abstract}

This study discusses the isomorphic learning model based on the Qur'an in early childhood Islamic education. This study uses a descriptive qualitative method which was confirmed by three educators at PIAUD Amanah Bunda Tangerang during December 2019 to February 2020 through deep interviews. Research shows that in applying the isomorphic learning model, educators have several obstacles, namely: lack of parental support, lack of support from the surrounding environment, and lack of ability of educators to explore educational concepts in the Qur'an. Some of these obstacles can be overcome by conducting home visits, educational partners, and upgrading the study of the Qur'an. This study also shows that to foster noble character, it is carried out by introducing moral education, worship education and monotheism education. If associated with the isomorphic learning model, moral education is related to the disciplines of psychology, sociology, anthropology. While worship education is closely related to the science of health, nutrition and physiology. Finally, monotheism education is related to the science of neuroscience, aiming to optimize the work of the mind to study all of Allah's creations that exist on earth and in the sky. Thus, the isomorphic learning model based on the Qur'an which focuses on aspects of faith and morality as the foundation for early childhood Islamic education becomes an obligation to be implemented.

\begin{abstract}
Abstrak
Kajian ini membahas tentang model pembelajaran isomorfis berbasis alQur'an pada pendidikan Islam anak usia dini. Kajian ini menggunakan metode kualitatif deskirptif yang dikonfirmasikan kepada tiga pendidik di PIAUD Amanah Bunda Tangerang selama bulan Desember 2019 sampai dengan bulan Februari 2020 melalui wawancara mendalam (deep interview). Penelitian menunjukkan bahwa dalam menerapkan model pembelajaran isomorfis, pendidik memiliki beberapa kendala, yaitu: kurangnya dukungan orang tua, kurang dukungan lingkungan sekitar, dan kurangnya kemampuan pendidik dalam menggali konsep-kosep pendidikan dalam al-Qur'an. Beberapa kendala ini dapat diatasi dengan melakukan home visit (kunjungan), mitra pendidikan, dan penataran kajian al-Qur'an. Kajian ini juga memperlihatkan bahwa untuk membina akhlak yang mulia, dilakukan dengan pengenalan pendidikan akhlak, pendidikan ibadah dan pendidikan tauhid. Jika dihubungkan dengan dengan model pembelajaran isomorfis, pendidikan akhlak berkaitan dengan disiplin ilmu psikologi, sosiologi, antropologi. Sementara pendidikan ibadah berkaitan erat dengan ilmu kesehatan gizi dan fisiologi. Terakhir pendidikan tauhid berkaitan dengan ilmu nourosains, bertujuan untuk mengoptimalisasi kerja akal untuk
\end{abstract}

\footnotetext{
${ }^{1}$ Institut PTIQ Jakarta, Indonesia

Email: madesaihu@ptiq.ac.id 
mengkaji segala ciptaan Allah SWT yang ada di bumi dan di langit. Dengan demikian, model pembelajaran isomorfis berbasis al-Qur'an yang menintik beratkan pada aspek akidah dan akhlak sebagai pondasi bagi pendidikan Islam anak usia dini menjadi suatu kewajiban untuk diimplentasikan.

\section{PENDAHULUAN}

Berbagai macam model pemebelajaran pada pendidikan Islam anak usia dini (PIAUD) yang oleh sebagian pakar dikatakan sebagai peletakan dasar pembinaan akhlak ternyata belum sepenuhnya berhasil (Hidaya \& Aisna, 2020, hal. 11-22). Banyak pendidik menghadapi kendala dalam membina akhlak peserta didik yang bersumber dari orang tua, lingkungan, dan juga lembaga (Mayasarokh \& Rohman, 2019, hal. 167-185; Nugraha, 2020, hal. 95). Pendidikan akhlak juga membutuhkan satu model pembelajaran yang terintegrasi (isomorfis) dengan beberapa disiplin, seperti psikologi, fisiologi, sosiologi, antropologi, kesehata dan gizi serta neurosains dengan menjadikan al-Qur'an sebagai rujukan awal (Novia Ulfa \& Citra Dewi, 2016, hal. 72; Wartini, 2016, hal. 1; Yuliani, 2011, hal. 10). Sementara itu, tidak semua pendidik pada lembaga pendidikan anak usia dini memiliki kompetensi pedagogik mumpuni dalam mengajarkan dan mengintegrasikan praktik pembelajaran di PIAUD dengan nilai-nilai al-Qur'an (Asiyah, 2020, hal. 45-53; Nurlaili, 2018, hal. 240). Jadi tidak semua model pembelajaran yang bertujuan membina akhlak di PAUD bekerja sabagaimana yang dibayangkan akibat kendala dan tantangan yang dihadapi pendidik dalam mengembangkan model pembelajaran untuk membentuk akhlak yang baik.

Studi hubungan antara model pembelajaran dengan pembentukan akhlak telah berkembang dari studi awal tentang materi ajar, tentang fungsi model pembelajaran hingga studi tentang solusi gagalnya pendidikan akhlak di era kontemporer. Pada awalnya materi ajar pendidikan akhlak yang dipraktikkan pada PIAUD bersifat konvensional sehingga hasil yang diperoleh dari aktivitas belajar kurang maksimal dalam mengembangkan seluruh potensi anak (Pentury, 2018, hal. 14-21). Studi mutakhir melihat model pembelajaran yang komprehensif merupakan salah satu faktor dalam kemajuan pendidikan yang memberikan banyak kemungkinan dalam proses belajar serta menjadikan pendidikan akhlak semakin modern dan terbuka (Tatminingsih, 2019, hal. 183). Gagalnya pendidikan akhlak pada anak usia dini yang berdampak pada karakter manusia di usia dewasa disebabkan oleh model pembelajaran yang kurang komprehensif (Hewi \& Asnawati, 2020, hal. 158). Dari ketiga kecenderungan studi tersebut tampak bahwa model pembelajaran pendidikan akhlak telah diposisikan sebagai kekuatan objektif yang memiliki yang memilik daya "paksa" manusia. Sementara perspektif subjekif dalam beradaptasi dan kesulitan berhadapan dengan pembinaan akhlak belum terpetakan dengan baik.

Tulisan ini didasarkan pada argumen bahwa model pembelajaran komprehensif (isomorfis) tidak hanya menawarkan fungsi-fungsi kemajuan dalam pendidikan akhlak, tetapi juga bisa menciptakan persoalan baru yang harus dihadapi. Model pembelajaran isomorfis sebagai faktor dan proses membutuhkan kelengkapan persyaratan dan fasilitas untuk dapat diimplementasikan secara maksimal. Pada saat yang sama model pembelajaran memiliki kekuatan untuk mengharuskan suatu sistem baru dalam proses pembelajaran. Model pembelajaran isomorfis berbasis al-Qur'an mengubah tradisi pembelajaran dari dogmatik-konvensional menjadi kritis-kontekstual. Dengan demikian, model pembelajaran isomorfis berbasis al-Qur'an menuntut adanya integrasi keilmuan yang membutuhkan suatu adaptasi sekaligus menghadirkan tantangan baru bagi pedidik dan juga lembaga.

Tulisan ini bertujuan secara khusus menunjukkan pengalaman pendidik dalam mengimplementasikan model pembelajaran isomorfis (integrasi keilmuan) berbasis al-Qur'an pada pendidikan Islam anak usia dini (PIAUD). Selain mengidentifikasi tipe kesulitan dan tantangan yang dihadapi, tulisan ini juga menunjukkan strategi yang ditempuh dalam menghadapi permasalahan pembelajaran. Implementasi model pembelajaran isomorfis dalam pembinaan akhlak memberikan beban pada pendidik dan juga lembaga serta orang tua (keluarga) peserta didik. Model pembelajaran isomorfis berbasis al-Qur'an melahirkan tradisi baru dalam pendidikan yang membutuhkan 
adaptasi. Dengan kata lain, tulisan ini menguji bahwa dibalik kemudahan yang diberikan model pembelajaran isomorfis berbasis al-Qur'an, banyak kesulitan dan tantangan yang harus dihadapi pendidik, orang tua, dan lembaga pendidikan.

\section{METODE}

Penelitian tentang model pembelajaran isomorfis berbasis al-Qur'an bersifat kualitatif deskriptif. Sesuai dengan pengertiannya, studi ini menyajikan gambaran lengkap mengenai setting sosial atau dimaksudkan untuk mengeksplorasi dan klarifikasi mengenai suatu fenomena atau kenyataan sosial pada praktik pembelajaran di tingkat anak usia dini. Selain itu, penelitian ini juga didasarkan pada al-Qur'an, buku, jurnal, yang diperoleh secara online terkait dengan pendidikan akhlak. Data dari sumber online dipilih berdasarkan pada tema yang menjadi fokus penelitian, yakni yang menyangkut masalah kendala dalam model pembelajaran isomorfis, kompetensi pendidik, dan kesiapan lembaga dalam mendukung aktivitas pembelajaran. Data secara online, didapatkan dari beberapa jurnal internasional, jurnal nasional terakreditasi, dan beberapa media online lainnya. Selain dikelompokkan ke dalam tema yang relevan, data diseleksi mencakup pengalaman langsung pendidik, orang tua, dan stakeholder lembaga pendidikan, serta kasus-kasus yang merefleksikan kendala pendidik dalam pembelajaran. Dengan demikian, kesulitan belajar-mengajar dalam studi ini meliputi kesulitan personal, infrastruktural, dan struktural.

Disamping berdasar pada sumber online, fenomena ini juga dikonfirmasikan kepada beberapa pelaku pendidikan di PAUD Amanah. Partisipan tidak dibatasi pada pendidik yang memiliki kompetensi menggunakan model pembelajaran isomorfis, tetapi juga kepada pendidik yang kurang memiliki pengalaman dalam mengajar akibat tingkat literasi yang masih terbatas, namun pada saat yang sama pendidik yang belum memiliki pengalaman mengajar ini menjadi salah salah satu unsur dalam transformasi pendidikan pada anak usia dini. Agar data yang diperoleh kuat, hasil dari studi pusataka tersebut, dikonfirmasikan kepada pendidik pada PIAUD Amanah Budan Tangerang, melalui prosedur wawancara secara terbuka mencakup beberapa bidang data: 1) Data terkait model pembelajaran isomorfis yang digunakan dalam membentuk karakter anak; 2) Kompetesi pedagogik pendidik; 3) Dukungan orang tua dalam belajar mengingat anak usia dini membutuhkan perhatian ekstra; 4) Keterlibatan pengurus yayasan dalam menyediakan infrastruktur sekolah; 5) Sistem pendidikan dan kurikulum yang mendukung proses implementasi model pembelajaran isomorfis dalam membentuk karakter anak.

Penelitian ini berlangsung mulai dari bulan Desember 2019 sampai dengan Februari 2020 pada saat pandemi, tetapi di lembaga ini proses belajar mengajar dilakukan tatap muka dikarenakan peserta didiknya tidak terlalu banyak, di samping itu proses pembelajaran dibagi menjadi 2 shift dengan tetap menjaga jarak dan menggunakan masker. Infroman dalam penelitian ini berjumlah tiga orang yang dianggap mewakili dari topik pembahasa dicari. Pendidik yang menjadi partisipan, diwawancarai atas kesadaran dan kesediaan, antara lain, RI, kepala sekolah. Dipilihnya kepala sekolah sebagai informan, didasarkan pada fakta bahwa kepala sekolah merupakan aktor pendidikan yang paling bertanggung jawab di sekolah. Kemudia R2 dan R3, merupakan wali kelas A dan B sebagai pengampu utama proses pembelajaran di kelas. Selanjutnya pertanyaan diajukan satu persatu dalam suasana terbuka di dalam kelas maupun diluar kelas. Pada saat yang sama dilakukan probing yaitu suatu cara mendalam jawaban sebagaimana yang ditunjukkan oleh Singarimbun dan Efendi (Effendi, 1989, hal. 51).

Data literatur dan juga wawancara diklasifikasi secara sistematis untuk mempertegas tipe kesulitan atau kendala yang dialami pendidik dalam proses pembelajaran atau untuk menguji, apakah data itu sah atau tidak. Pemeriksaan terhadap keabsahan data pada dasarnya, selain digunakan untuk menyanggah balik yang dituduhkan kepada penelitian kualitatif yang mengatakan tidak ilmiah, juga merupakan sebagai unsur yang tidak terpisahkan dari tubuh pengetahuan penelitian kualitatif (Moleong, 2016, hal. 320). Sebagaimana dikatakan oleh Sugiyono, bahwa ada 
empat langkah yang harus dilakukan untuk menguji kebasahan data. Antara lain: credibility, transferability, dependability, dan confirmability (Sugiyono, 2013, hal. 270).

Pada tahap credibility, penulis melakukan seleksi dari data literatur yang diperoleh dengan cara memilih beberapa buku referensi yang dianggap otoritatif, juga dengan memilih jurnal-jurnal nasional terakreditasi terkait dengan pendidikan akhlak dengan melihat seberapa dalam hasil kajiannya. Dalam prosesnya, penulis melakukan: Perpanjangan Pengamatan, meningkatkan kecermatan dalam penelitian, dan Triangulasi. Kemudian dilanjutkan dengan tahap transferability, penulis melakukan validitas eksternal untuk menunjukkan derajat ketepatan atau dapat diterapkannya hasil penelitian ke populasi di mana sampel tersebut diambil. Selanjutnya diikuti dengan dependability dencara melakukan audit terdapa keseluruhan proses penelitian, dari mulai menentukan masalah, terjun ke lapangan, memilih sumber data, melaksanakan analisis data, melakukan uji keabsahan data, sampai pada pembuatan laporan hasil pengamatan. Terakhir, penulis melakukan confirmability, yaitu melakukan konfirmasi terkait dengan topik penelitian pada beberapa stakeholder pendidikan di PIAUD Amanah Budan Tangerang untuk membutikan objektivitas dari hasil penelitian sekaligus agar penelitian dapat dipertanggung jawabkan.

Selanjutnya data dianalisis melalui tiga tahapan: restatement data, deskripsi data, dan interpretasi data. Restatement dilakukan dengan mengacu pada kutipan-kitupan literatur dan hasil wawancara berdasarkan sudut pandang pendidik.deskripsi data dilakukan untuk menunjukkan pola atau kecenderungan menyangkut tipologi kendala dalam mengimplementasikan model pembelajaran isomorfis dalam perspektif al-Qur'an. Terakhir, proses interpretasi dilakukan dengan memperhatikan konteks individual, sosial, dan institusional yang menjadi dasar kendala pendidik dalam proses pembinaan karakter dalam aktivitas belajar-mengajar.

\section{HASIL PENELITIAN DAN PEMBAHASAN}

Model pembelajaran isomorfis di sebagain PAUD diimplementasikan secara berbeda-beda. Banyak para pendidik mengalami kendala dalam menerapkannya akibat kurangnya dukungan dari orang tua, lingkungan, dan lembaga pengelola. Kendala ini ditemukan pada lemahnya kompetensi pendidik dalam mengintegrasikan beberapa disiplin keilmuan dalam materi ajar, khsusunya yang terkait dengan internalisasi nilai-nilai al-Qur'an dalam setiap proses belajar-mengajar. Ketiga kendala inilah yang akan dibicarakan pada bagain-bagian berikut ini.

Model pembelajaran isomorfis merupakan konsep pembelajaran yang mengintegrasikan beberapa disiplin keilmuan, diantaranya: psikologi, sosiologi, fisiologi, ilmu pendidikan anak, antropologi, humaniora, kesehatan dan gizi serta neurosains (Sujiono, 2009, hal. 10). Integrasi disipilin keilmuan ini mengharuskan adanya adaptasi dan peningkatan daya dukung seluruh komponen pendidikan yang bertuuan untuk memperlancar proses belajar mengajar dengan menjadikan nilai-nilai pendidikan anaka dalam al-Qur'an sebagai pondasi dalam menentukan materi ajar.

Kendala yang dihadapi pendidik untuk mengimplementasikan model pembelajaran isomorfis, pertama menyangkut masalah kurangnya dukungan orang tua, sebagaimana tampak dalam pengalaman R1:

"Orang tua siswa di lembaga kami kurang memberikan dukungan terhadap model pembelajaran isomorfis. Hal ini disebabkan banyak di antara orang tua yang menyekolahkan anaknya di PAUD kami sebatas pada penitipan anak, karena mereka umunya bekerja dan tidak memiliki waktu untuk mengurus anak. Di samping itu, orang tua juga kurang memberikan situmulasi sebagai akibat dari sibuknya mereka bekerja dan asupan nutrisi yang diberikan anakjuga tidak maksimal, padahal model pembelajaran yang ini membutuhkan tingkat protein yang tinggi agar otak dan tubuh anak menjadi sehat. Untuk mengatasi hal ini, pihak sekolah sering melakukan home visit serta memberikan sosialisasi kepada orang tua tentang model pembelajaran yang kami terapkan di sekolah”. 
Pengalaman R1 menunjukkan betapa kurangnya dukungan orang tua disebabkan faktor kesibukan yang sedikit "melupakan" partisipasinya dalam kegiatan belajar anak. Padahal dukungan orang tua menjadi salah satu faktor penting dalam menyukseskan proses belajar-mengajar pendidikan anak usia dini (Wahyuni, 2019, hal. 61-72). Peran orang tua dalam mengembangkan keterampilan dapat memberikan kepercayaan dan kesempatan, orang tua juga diharapkan memberi penguatan lewat pemberian rangsangan ganjaran atau hadiah kalau anak bertingkah laku positif atau hukuman kalau ia melakukan kesalahan. Dengan begitu anak bisa berkembang menjadi makhluk sosial yang sehat dan bertanggung jawab. Oleh karena itu, anak yang cerdas, walaupun umurnya 6 tahun, tetapi sudah mampu mengikuti permainan yang membutuhkan strategi berfikir seperti catur. Biasanya anak yang cerdas lebih suka bermain dengan anak yang usia lebih tua, sedangkan anak yang kurang cerdas merasa lebih cocok dengan anak lebih muda usianya (Hasiana, 2020, hal. 118-125). Sementara dalam ilmu antropologi pendidikan berupaya menemukan pola budaya belajar masyarakat yang dapat menciptakan perubahan sosial. Demikian juga mengenai perwujudan kebudayaan para pengambil kebijakan pendidikan yang berorientasi pada perubahan sosial budaya berupa enculturation (pembudayaan/pewarisan), socialization (sosialisasi/ pemasyarakatan), internalization, education (pendidikan), dan schooling (persekolahan) yang dapat dilakukan oleh orang tua (Septiarti, 2017, hal. 78).

Responden juga menjelaskan bahwa mengatasi hal ini dilakukanlah home visit yang bertujuan untuk menginformasikan tentang pentingya dukungan orang tua terhadap belajar anak. Beberapa keuntungan dari program home visit adalah selain sebagai ajang silaturrahim pihak sekolah dengan orang tua, home visit juga dapat meningkatkan pengertian dan pemahaman orangtua mengenai perkembangan anak, mengurangi kesalahan penanganan pada penanganan, serta dapat meningkatkan kualitas lingkungan dimana anak tinggal (Johnson, 2009, hal. 20).

Jika dipandang dalam disiplin ilmu psikologi, home visit berguna untuk memantapkan kondisi, karena dapat menyentuh aspek kejiwaan anak. Sementara jika dilihat dari sudut pandang sosiologi, home visit ini dapat dikategorisasikan dalam disiplin ilmu sosiologi. Di sini, orang tua, anak dan pihak sekolah dapat berinteraksi tidak saja dengan teman sebaya, orang dewasa dan masyarakat luas agar dapat menyesuaikan diri dengan baik sesuai apa yang diharapkan oleh bangsa dan negara. Ada kaitan erat antara keterampilan bergaul dengan masa bahagia dimasa kanak-kanak. Kemampuan anak untuk menyessuaikan diri dengan lingkungan. Penerimaan lingkungan serta pengalamanpengalaman positif lain selama melakukan aktivitas sosial merupakan modal dasar yang sangat penting untuk satu kehidupan sukses dan menyenangkan dimasa yang akan datang, apa anak dipupuk dimasa kanakkanak akan mereka petik buahnya dimasa dewasa kelak. Namun juga perlu diketahui bahwa keterampilan bergaul harus dipelajari, dan masa awal kehidupan, sehingga anak dapat belajar dari orang-orang yang terdekat dengan dalam hal ini, orang tua dan juga guru. Itu sebabnya, selain membimbing dan mengajarkan anak bagaimana cara bergaul dengan tepat, orang tua juga dituntut untuk menjadi model yang baik bagi anaknya. Apalagi biasanya anak yang cerdas lebih suka bermain dengan anak yang usia lebih tua, sedangkan anak yang kurang cerdas merasa lebih cocok dengan anak lebih muda usianya (Irma, Nisa, \& Sururiyah, 2019, hal. 214).

Tentang pentingnya peranan orang tua dalam pendidikan anak di lingkungan keluarga ini Allah Swt berfirman dalam Surat At-Tahrim/66: 6

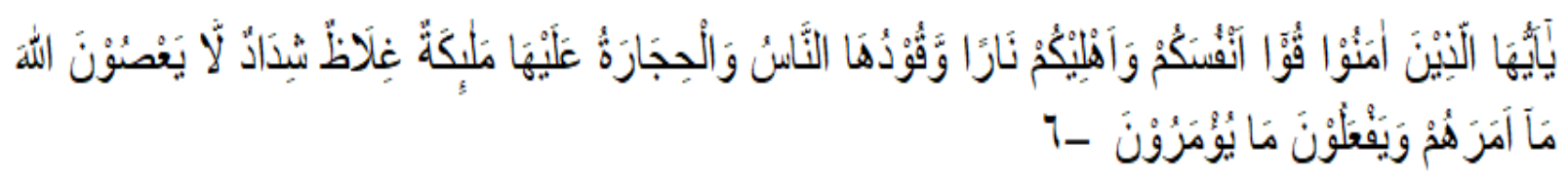


Hai orang-orang yang beriman, peliharalah dirimu dan keluargamu dari api neraka yang bahan bakarnya adalah manusia dan batu: Penjaganya malaikat-malaikat yang kasar, keras, dan tidak mendurhakai Allah terhadap apa yang diperintahkan-Nya kepada mereka dan selalu mengerjakan apa yang diperintahkan.

Pendidikan akhlak dengan mengintegrasikan berbagai displin keilmuan yang berbasis pada al-Qur'an, menekankan dan lebih menumbuhkan pemahaman tentang universiltas agama serta bagaimana agama diamalkan dan diaplikasikan dalam kehidupan sehari-hari. Penanaman nilai-nilai akhlak melalui integrasi keilmuan (isomorfis) juga disesuaikan dengan tahapan perkembangan anak serta keunikan yang dimiliki oleh setiap anak. Contohnya dalam pembiasaan ibadah, seorang anak diajarkan sholat lima waktu, puasa, dan lain-lain.

Selain kurangya dukungan orang tua, implementasi model pembelajaran isomorfis berbasis al-Qur'an, juga kurang didukung oleh lingkungan sekirat anak. Hal ini sebagaimana diakui oleh R2.

"Faktor eksternal dalam hal ini lingkungan sangat mempengaruhi sikap dan perilaku anak, tetapi pada kenyataannya, anak didik kami berada dilingkungan yang kurang mendukung karena kebetulan sekolah kami berada dilingkungan (kampung) yang intensitas belajarnya rendah sebagai akibat banyak sarana bermain play station dihampir setiap gang dilingkungan sekolah kami. Anak-anak selepas pulang sekolah suka bermain PS, sehingga banyak diantara anak-anak kami kurang fokus dalam belajar, dan kalaupun dipaksakan anak-anak kurang memiliki motivasi. Untuk mengatasi hal ini, beberapa pendidik di lembaga kami, membata semacam mitra kerja dalam belajar, kami menyebutnya dengan istilah mendidi bersama. Tujuan dari mitra medidik bersama ini adalah agar dirumah orang tua lebih memperhatikan atau menignkatkan tingkat pengawasan kepada anak-anaknya ketika berinteraksi dengan lingkungan sekitar"

Pengalaman R2 ini menunjukkan bahwa lingkungan merupakan salah satu instrumen pendidikan yang sangat memepngaruhi sikap dan perilaku anak. Sebagaimana dikatakan oleh John Dewey bahwa pendidikan merupakan transaksi antara person dengan lingkungannya (Dewey, 1964, hal. 9). Selain itu, Dewey, memandang peserta didik sebagai sesuatu yang fungsional dalam hidup sosial. Peserta didik dalam pandangan progressivisme adalah organisme yang mengalami satu proses pengalaman. Sebab peserta didik merupakan bagian integral dari lingkungan, peristiwaperistiwa yang terjadi di masyarakat, interaksi sosial, perasaan, pikiran dan benda-benda di sekitarnya (Syam, 1984, hal. 50). Jika lingkungan belajar itu damai, menyenangkan, penuh toleransi, maka kondisi tersebut berdampak pada pengalaman belajar dan kondisi kejiwaan yang didapat oleh peserta didik. Pendidikan adalah rekonstruksi atau reorganisasi pengalaman serta meningkatkan kemampuan untuk menentukan arah bagi pengalaman berikutnya berangkat dari pengalaman yang didapat sebelumnya.

Pembelajaran yang menjadikan lingkungan sebagai landasan dalam kerangka kerjanya mempromosikan pengetahuan, keahlian-keahlian, sikap dan nilai-nilai yang diperlukan untuk membawa perubahan tingkah laku peserta didik (Chaer, 2016, hal. 234-239), yang dapat menghubungkan kecerdasan intelektual "supra-rasional" dan kesadaran spiritual "supra-religius" pada puncak-puncak pencapaian daya kreativitas peserta didik dan disinilah letak puncak akhlak anak. Ada banyak ragam pendidikan yang didapatkan seorang anak secara tidak langsung ketika berinteraksi di masyarakat, seperti pembentukan kebiasaan, pembentukan pengetahuan, sikap, minat, maupun pembentukan kesusilaan dan keagamaan. Manfaat yang diperoleh dari pembelajaran di lingkungan alam adalah: 1) Penggunaan lingkungan alam memungkinkan terjadinya proses belajar yang lebih bermakna (meaningfull learning) sebab anak dihadapkan dengan keadaan dan situasi yang sebenarnya. Hal ini akan memenuhi prinsip kekonkritan dalam belajar; 2) Penggunaan lingkungan alam sebagai sumber belajar akan mendorong pada penghayatan 
nilai-nilai atau aspek-aspek kehidupan yang ada di lingkungannya; 3) Penggunaan lingkungan alam dapat menarik miant anak (Jumiatin, Windarsih, \& Sumitra, 2020, hal. 1-8).

Pembelajaran berbasis pada lingkungan diafirmasi oleh al-Qur'an Surat Al-Ghasiyyat/88: 17-20:

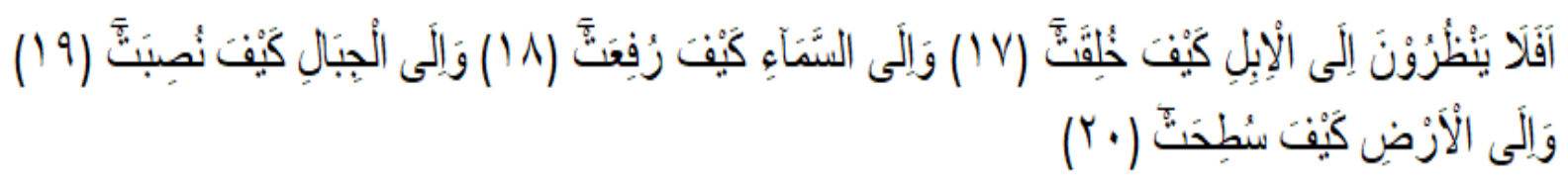

Maka tidakkah mereka memperhatikan unta, bagaimana diciptakan? dan langit, bagaimana ditinggikan? Dan gunung-gunung bagaimana ditegakkan? Dan bumi bagaimana dihamparkan?

Dengan demikian pentingnya lingkungan sebagai landasan pembelajaran menjadi sesuatu yang harus diperhatikan, dibenahi, dan dikembangkan. Model pembelajaran isomorfis juga membutuhkan kompetensi yang tidak bisa dikatakan mudah. Seorang guru yang akan menerapkan model pembelajaran isomorfis harus memiliki kompetensi pedagogik yang komprehensif (Yulyani, Kazumaretha, Arisanti, Fitria, \& Desyandri, 2020, hal. 184). Tidak saja memahami tentng teori-teori belajar, tetapi juga harus memiliki kemampuan dalam menelaah serta mengeksplore nilai-nilai pendidikan dalam al-Qur'an. (Zainal Arifin, Yaqin, 2019, hal. 416-427). Pentingnya pemahaman teori belajar yang dikorelasikan dengan al-Qur'an membuat guru memiliki kualitas yang mumpuni dalam mendidik anak.

Kerangkan isomorfis sebagai satu pendekatan pembelajaran ayng menitik beratkan pada integrasi keilmuan, harus didasarkan pada al-Qur'an sebagai sumber primer umat Islam. Meski sulit diimplementasikan, tetpi upaya untuk membumikan al-Qur'an sebagai basis pendidikan akhlak menjadi sebuah keharusan. Hal ini tampak pada uraian yang disajikan oleh $\mathrm{R} 3$, pendidik PAUD Amanah Bunda Tangerang.

"Dalam upaya mendidik akhlak, kami menggunakan al-Qur'an sebagai dasar dalam mendidik. Pendidikan yang kami berikan tumumnya tentang pendidikan akhlak, meliputi: tauhid, ibadah, fisik, dan sosial. Kami berkeyakinan melalui integrasi alQu'an dalam setiap aktivitas pendidikan yang kami jalankan, inshaAllah akan memberikan hasil yang terbaik. Kami mengakui, bahwa ada banyak pendidik yang kurang mampu menelaah konsep-konsep pendidikan dalam al-Qur'an, maka dari itu kepala sekolah kami dalam setiap awal semester mengundang ahli pendidikan alQur'an yang berasal dari kampus PTIQ dan IIQ Jakarta untuk memberikan penataran tentang konspetualisasi pendidikan dalam al-Qur'an. Alhamdulillah sedikit demi sedikit kami dapat memahami dan mampu menelaah nalar pendidikan anak dalam al-Qur'an".

Dari pengakuan yang ditunjukkan oleh R3, bahwa banyak pendidik yang kurang memiliki kompetensi dalam menggali konsept-konsep pendidikan dalam al-Qur'an. Konseptualisasi isomorfis sebagai sebuah model pembelajaran terintegrasi sebenarnya sudah tertuang dalam 6666 ayat alQur'an, apalagi yang terkait dengan pendidikan anak.

Terkait dengan pendidikan anak, Islam tentu meiliki dasar yang kuat sebagaimana dijelaskan dalam Surat Luqman/31: 13-15, memiliki dua kategori bila dihubungkan dengan pendidikan yang diberikan kepada anak: 1) Berkaitan dengan metode yang digunakan oleh Luqman dalam pendidikan anak; 2) Membahas tentang materi-materi yang diberikan Luqman dalam pendidikan anak. Sebagaimana dijelaskan dibawah ini:

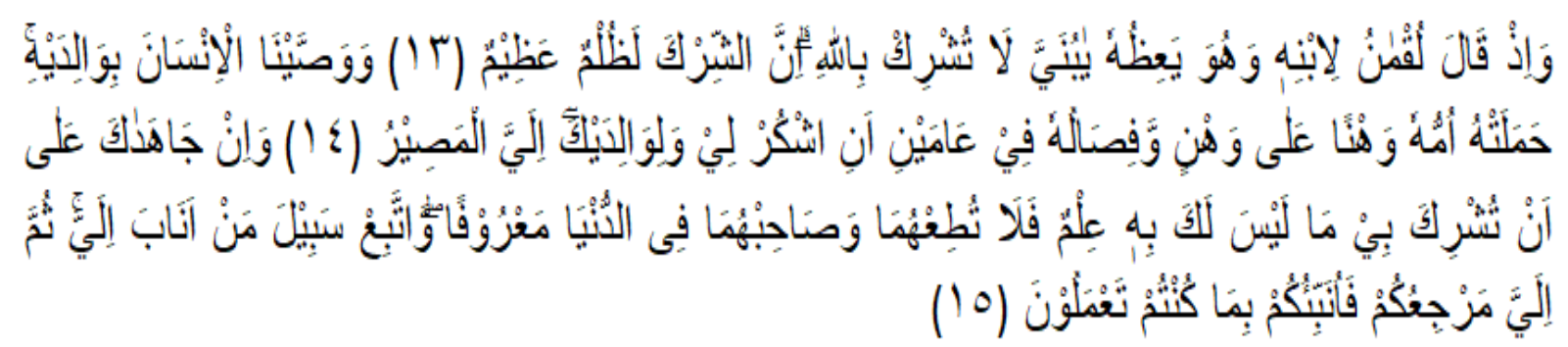


Dan (ingatlah) ketika Luqman berkata kepada anaknya, di waktu ia memberi pelajaran kepadanya: "Hai anakku, janganlah kamu mempersekutukan Allah, Sesungguhnya mempersekutukan (Allah) adalah benar-benar kezaliman yang besar, Dan Kami perintahkan kepada manusia (berbuat baik) kepada dua orang ibu-bapanya; ibunya telah mengandungnya dalam Keadaan lemah yang bertambah- tambah, dan menyapihnya dalam dua tahun. Bersyukurlah kepadaku dan kepada dua orang ibu bapakmu, hanya kepada-Kulah kembalimu, dan jika keduanya memaksamu untuk mempersekutukan dengan aku sesuatu yang tidak ada pengetahuanmu tentang itu, maka janganlah kamu mengikuti keduanya, dan pergaulilah keduanya di dunia dengan baik, dan ikutilah jalan orang yang kembali kepada-Ku, kemudian hanya kepada-Kulah kembalimu, maka Kuberitakan kepadamu apa yang telah kamu kerjakan,

Tujuan pendidikan anak dalam surat Luqman ayat 13-15 identik dengan tujuan hidup manusia itu sendiri, sebab pendidikan bertujuan untuk memelihara kehidupan manusia itu sendiri (Arief, 2002, hal. 110). Tujuan pendidikan juga berarti perubahan yang diinginkan dan diusahakan melalui proses pendidikan terhadap individu, masyarakat maupun lingkungan. Intinya ayat ini membahas tentang budi pekerti, sopan santun dan akhlak yang tinggi. Ketika semuanya dapat direalisasikan dengan baik dalam kehidupan masyarakat maka dapat menciptakan islam yang rahmatan lil alamin. Beberapa pendidikan itu adalah:

Pertama, pendidikan akhlak, yaitu gambaran tingkah laku dalam jiwa yang dari padanya lahir perbuatan perbuatan dengan mudah tanpa memerlukan pemikiran dan pertimbangan. Pendidikan akhlak ini tediri dari akhlak kepada Allah SWT, akhlak kepada kedua orang tua, akhlak kepada sesama manusia, dan akhlak kepada diri sendiri. Bentuk perbuatan akhlak meliputi: 1) Akhlak terpuji (Akhlak al-Mahmudah), yang berarti menghilangkan semua adat kebiasaan yang tercela yang sudah digariskan dalam agama Islam serta menjauhkan diri dari perbuatan tercela tersebut atau membiasakan kebiasaan yang baik melakukannya dan mencintainya. Selain itu akhlak terpuji juga dibagi menjadi dua: a) Taat Lahir yang berarti melakukan seluruh amal ibadah yang diwajibkan Tuhan yang dkerjakan oleh anggota lahir, seperti taubat, berbuat baik dan menjauhi kemungkaran, dan syukur; b) Taat batin, yaitu segala sifat baik dan terpuji yang dilakukan oleh anggota batin (hati), seperti tawakal, sabar dan qana'ah, husnudzan kepada Allah (Zahrudin, 2004, hal. 153); 2) Akhlak Tercela (Akhlaq al-Mazmumah), yang berati segala tingkah laku manusia yang dapat membawanya kepada kebinasaan dan kehancuran diri. Selain itu akhlak tercela juga akan membawa pelakunya kedalam sesuatu yang buruk baik di dunia maupun di akhirat kelak. Di sini yang termasuk kedalam golongan akhlak tercela yaitu adalah maksiat (pelanggaran orang berakal), meliputi maksiat lahir seperti maksiat lisan, maksiat telinga, maksiat tangan, dan lain sebagainya. Sementara maksiat batin meliputi marah (ghadab), dengki (hasud), dan sombong (takabur).

Kedua, pendidikan ibadah. Setelah mengenalkan lalu membimbing berbagai macam ibadah, baik ibadah yang khusus (madhah) seperti sholat, puasa, zakat, haji, dan lain sebagainya, peserta didik juga dibimbing untuk memahami ibadah yang umum (gharu madhah), saling menghormati, menyayangi, bersedekah, sampai kepada bersikap toleran kepada peserta didik yang berbeda suku, ras, dan golongan. Menanamkan pemahaman dan pengamalan ibadah kepada peserta didik melalui pemupukan rasa ikhlas dalam melakukannya.

Ketiga, pendidikan sosial. Dimensi sosial merupakan salah satu ajaran Islam yang paling menonjol, karena segala perintah Allah Swt berujung pada kesejahteraan manusia. hal ini penting utuk ditanamkan kepada anak didik, terutama yang berkaitan dengan akhlak kepada sesama. Allah Swt berfirman dalam surat Luqman/31: 18:

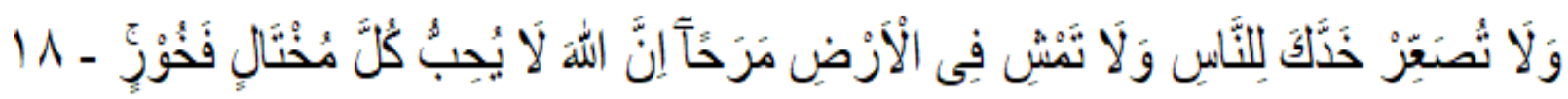


Dan janganlah kamu memalingkan mukamu dari manusia (karena sombong) dan janganlah kamu berjalan di muka bumi dengan angkuh. Sesungguhnya Allah tidak menyukai orang-orang yang sombong lagi membanggakan diri.

Allah SWT, tidak membeda-bedakan warna kulit, ras, bahasa dan lain sebagainya, akan tetapi yang membedakan tinggi rendahnya kualitas derajat seseorang ditentukan oleh ketakwaannya dan prestasi kerjanya yang bermanfaat bagi manusia (Tafsir, 2005, hal. 125). Selain itu sosialisasi juga merupakan suatu proses yang dialami oleh setiap individu sebagai makhluk sosial di sepanjang kehidupannya, dari ketika ia dilahirkan sampai akhir hayatnya. Kewajiban pendidik (guru), orang tua pada proses sosialisasi di masa kanak kanak ini bertujuan untuk membentuk kepribadian anaknya. Apalagi al-Qur'an mengingatkan bahwa sesama manusia harus saling untuk berbuat amal baik sebagaimana tertera dalam surat Al-Qasas/28: 77

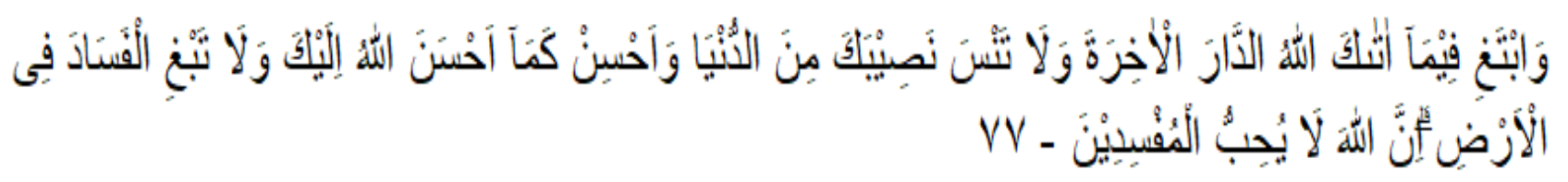

Dan carilah (pahala) negeri akhirat dengan apa yang telah dianugerahkan Allah kepadamu, tetapi janganlah kamu lupakan bagianmu di dunia dan berbuatbaiklah (kepada orang lain) sebagaimana Allah telah berbuat baik kepadamu, dan janganlah kamu berbuat kerusakan di bumi. Sungguh, Allah tidak menyukai orang yang berbuat kerusakan.

Ketiga, pendidikan tauhid. Pengetahuan tentang ketahudidan merupakan ajaran al Qur'an yang paling mendasar sekaligus misi utama rasul yang diutus Allah (Dahlan, 2010, hal. 200). Ketika Nabi Muhammad Saw diutus menyempurnakan akhlak, akhlak yang paling utama adalah akhlak kepada Allah SWT yang ini berarti tauhid. Manusia diperintahkan untuk menyembah Allah SWT serta tidak boleh menyekutukannya dengan apapun. Perkataan tauhid sangat erat hubungannya dengan kata wahid (satu atau esa), dalam bahasa Arab sebagai istilah yang dipergunakan dalam membahas ketuhanan. Tauhid merupakan keyakinan akan keesaan Allah SWT. Tauhid sangat erat kaitannya dengan keimanan. Jiwa yang beriman merupakan jiwa yang tidak cenderung kepada tindakan tindakan zalim (aniaya), karena pada dasarnya iman yang benar (al-iman ash shahih) tidak wajar dicampur dengan kezaliman. Intinya adalah kezaliman tidak mungkin tercampur dengan iman karena keimanan memiliki kecenderungan pada kebaikan, keadilan, kedamaian, keselamatan, dan kepada penunaian hak hak seperti yang di ajarkan oleh agama (Nawawi, 2011, hal. 56). Kata iman dengan berbagai bentuknya termuat sebanyak 600 kali dalam al-Qur'an . Hal menunjukkan bahwa iman dengan segala bentuknya menjadi tuntutan utama dalam ajaran Islam. Seperti disebutkan dalam surat Al-An'am/6: 82

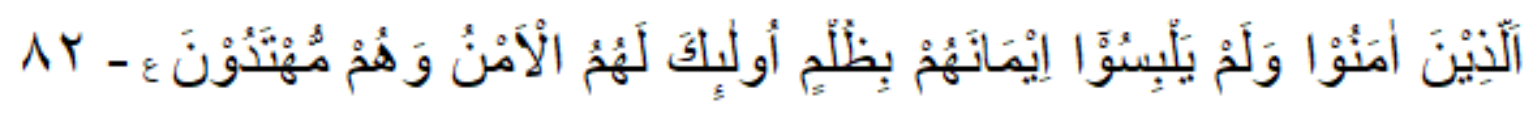

Orang-orang yang beriman dan tidak mencampuradukkan iman mereka dengan kezaliman (syirik), mereka Itulah yang mendapat keamanan dan mereka itu adalah orang-orang yang mendapat petunjuk"

Al-Qur'an mengajak manusia untuk bertauhid dengan cara menyebutkan manfaat dalam bertauhid, dalam bentuk ganjaran kebaikan dan pahala, baik di dunia maupun di akhirat. Al-Qur'an juga menerangkan dampak negatif dari sikap penentangan pada prinsip tauhid baik dalam bentuk akibat yang berupa hukuman hukuman di dunia maupun siksaan diakhirat. Perbuatan syirik 
manusia akan melahirkan balasan terburuk dan terjahat di akhirat. Dalam menegaskan prinsip tauhid, Allah Swt berfirman dalam surat Muhamad/47: 19.

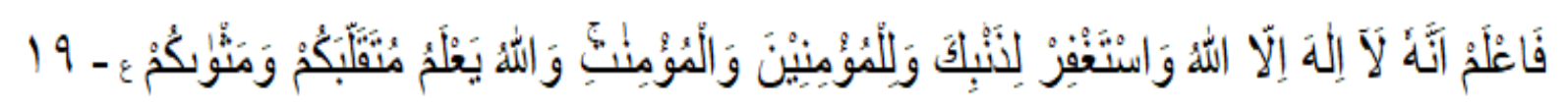

Maka ketahuilah, bahwa Sesungguhnya tidak ada Ilah (sesembahan, Tuhan) selain Allah dan mohonlah ampunan bagi dosamu dan bagi (dosa) orang-orang mukmin, laki-laki dan perempuan. dan Allah mengetahui tempat kamu berusaha dan tempat kamu tinggal.

Pendidikan tauhid (keimanan) haruslah diberikan kepada anak sejak dini barlah diikuti dengan pendidikan yang lain. Beberapa komponen pendidikan tauhid itu meliputi: a) Menyeru dan memerintahkan manusia untuk menyembah Allah SWT; b) Melarang menyekutukan Allah SWT; c) Menjelaskan nilai nilai positif yang lahir dari sikap positif; d) Menjelaskan sikap negatif dari sikap menentang prinsip tauhid; e) Menjelaskan balasan pahala di dunia dan di akhirat bagi orang yang bertauhid; f) Menjelaskan perbedaan antara orang yang mengesakan Allah SWT dan orang orang yang musyrik (Dahlan, 2010, hal. 200).

Berdasarkan pada uraian di atas dapat penulis pahami bahwa perlunya mengetahui dan menerapkan model pembelajaran isomorfis berbasis al-Qur'an pada pendidikan anak usia dini sebagai satu pendekatan, strategi, metode, teknik, dan taktik yang digunakan dalam mendidik sekaligus membimbing tumbuh kembang anak. Melalui pendidikan akhlak, ibadah, tauhid, dan sosial, sebenarnya sudah mencakup aspek-aspek yang terkandung dalam model pembelajaran isomorfis. Akhlak misalnya, ini sangat terkait dengan psikologi, sosiologi, antropologi. Sementara ibadah, ini erat kaitannya dengan kesehatan dan gizi dan fisologi karena ibadah meweajibkan kebersihan dan kesucian. Terakhir pendidikan tauhid, erat kaitannya dengan nourosains yang bertujuan untuk meningkatkan kinerja akal, emosional, dan spiritual anak dengan mempelajari segala ciptaan Allah SWT yang ada di bumi dan di langit dengan melibatkan konsep dasar ketauhidan. Meski telah banyak tokoh barat yang menggolongkan beberapa model pembelajaran dalam mendidik, umat Islam, seyogyanya berpedoman terhadap nilai-nilai ajaran Islam yang terkandung dalam al-Qur'an yang tentu saja tidak bertentangan dengan kemajuan zaman. Dengan mengetahui model pemebelajaran ini, setidaknya dapat menjadi satu pendekatan baru dalam mendidik anak dan dapat meningkatkan kecerdasan mereka, tidak saja cerdas akalnya, cerdas emosionlanya, tetapi juga cerdas spritualnya.

\section{SIMPULAN}

Kajian ini menunjukkan bahwa model pembelajaran isomorfis berbasis al-Qur'an, berkontribusi besar dalam mendidik akhlak peserta didik pada pendidikan anak usia dini. Dalam pendidikan islam anak usia dini, model Isomorfis yang disebut sebagai model pembelajaran integratif yang mengintegrasikan beberapa disiplin keilmuan seperti psikologi, fisiologi, sosiologi, kesehatan gizi, antropologi, dan neorosains, dapat dikembangkan dengan menjadikan al-Qur;an sebagai fondasi dalam penerapannya. Dimulai dari pemahaman pendidikan tauhid sebagai pendidikan dasar pengenalan dan pendidikan keyakinan terhadap ke-Esaan Tuhan, pendidikan ibadah, sebagai sebuah pendidikan yang bertujuan untuk membangun hubungan dengan tuhan dan sebagai perwujudan kesinambungan dan implementasi dari pendidikan tauhid, pendidikan akhlak, sebagai bekal anak mengadaptasikan diri dalam keluarga (orang tua) dan berintraksi dengan masyarakat serta lingkungannya dalam kehidupannya, bertujuan untuk mengarahkan anak suia dini agar memiliki akhlak yang baik dan menjauhi kemungkaran sedini mugkin. Kendati dalam praktiknya, pendidik memiliki berbagai tantangan seperti kurangnya dukungan orang tua, lingkungan belajar, dan kompetensi guru sebagaimana ditunjukkan oleh beberapa responden, tetapi dengan semangat mendidik yang tinggi hal ini dapat diatasi, apalagi jika menjadikan al-Qur'an sebagai basis utama dalam implementasinya. Karenanya implementasi model pembelajaran isomorfis di lembaga pendidikan Islam anak usia dini, menjadi suatu keharusan untuk pembinaan 
akhlak. Sebuah model pembelajaran yang menintik beratkan pada aspek aqidah dan akhlak bagi anak usia dini.

\section{DAFTAR PUSTAKA}

Arief, A. (2002). Pengantar Ilmu dan Metodologi Pendidikan Islam. Jakarta: Ciputat Press.

Asiyah, N. (2020). Penerapan Pembelajaran Tematik Dalam Penanaman Moral Anak Usia Dini. Journal of Basic Education Research, 1(2), 45-53. https://doi.org/10.37251/jber.v1i2.82

Chaer, M. T. (2016). Islam dan Pendidikan Cinta Damai. ISTAWA, 2(1), 73-94.

Dahlan, R. (2010). Kaidah-Kaidah Tafsir. Jakarta: Amzah.

Dewey, J. (1964). Democracy and Education, an Introduction to the Philosophy of Education. New York: The Macmillan Company.

Effendi, M. S. dan S. (1989). Metode Penelitian Survai. Jakarta: LP3ES.

Hasiana, I. (2020). Peran Orangtua Dalam Pendidikan Seksual Anak Usia Dini. Wahana, 72(2), 118125. https://doi.org/10.36456/wahana.v72i2.2725

Hewi, L., \& Asnawati, L. (2020). Strategi Pendidik Anak Usia Dini Era Covid-19 dalam Menumbuhkan Kemampuan Berfikir Logis. Jurnal Obsesi : Jurnal Pendidikan Anak Usia Dini, 5(1), 158. https://doi.org/10.31004/obsesi.v5i1.530

Hidaya, N., \& Aisna, Y. (2020). Pendidikan Karakter Anak Usia Dini sebagai Upaya Peningkatan Karakter Bangsa : Literature Review. Jurnal Hawa: Studi Pengarus Utamaan Gender dan Anak, 2(1), 11. https://doi.org/10.2930o/hawapsga.v2i1.2793

Irma, C. N., Nisa, K., \& Sururiyah, S. K. (2019). Keterlibatan Orang Tua dalam Pendidikan Anak Usia Dini di TK Masyithoh 1 Purworejo. Jurnal Obsesi : Jurnal Pendidikan Anak Usia Dini, 3(1), 214. https://doi.org/10.31004/obsesi.v3i1.152

Johnson, R. \&. (2009). Pendidikan Anak Usia Dini dalam Berbagai Pendekatan. Jakarta: Kencana Prenada Media Group.

Jumiatin, D., Windarsih, C. A., \& Sumitra, A. (2020). Penerapan Metode Holistik Integratif Dalam Meningkatkan Kecerdasan Interpersonal Anak Usia Dini di Purwakarta. Jurnal Tunas Siliwangi, 6(2), 1-8. https://doi.org/https://doi.org/10.2246o/ts.v6i2p\%25p.1715

Kurniawan, I. (2010). Risalah Al-Ghajali Terjemahan Buku Majmu'ah Rasail Al-Imam Al-Ghajali. Bandung: Pustaka Hidayah.

Mayasarokh, M., \& Rohman, A. (2019). IMPLEMENTASI PENDIDIKAN KARAKTER PADA ANAK USIA DINI DI KELOMPOK BERMAIN RABBANI. Jurnal Pelita PAUD, 3(2), 167-185. https://doi.org/https://doi.org/10.33222/pelitapaud.v3i2.547

Moleong, L. J. (2016). Metodologi Penelitian Kualitatif. Bandung: Remaja Rosdakarya.

Nawawi, R. S. (2011). Kepribadian Qur'ani (Jakarta: Imprint Bumi Aksara, 2011), h. 56. Jakarta: Imprint Bumi Aksara.

Novia Ulfa, R., \& Citra Dewi, H. (2016). Integrasi Pendidikan Karakter Dalam Pembelajaran Bahasa Inggris Pada Anak Usia Dini. Jurnal Faktor UNINDRA, 3(1), 65-72. https://doi.org/http://dx.doi.org/10.30998/fjik.v3i1.685

Nugraha, E. (2020). Implementasi Program Tahfizh Qur'an Di PAUD Inklusif Dengan Model HOTS. As-Sibyan: Jurnal Pendidikan Anak Usia Dini, 5(2), 95-106. https://doi.org/http://dx.doi.org/10.32678/as-sibyan.v5i2.3569

Nurlaili. (2018). Kompetensi Pedagogik Guru Paud Harapan Bunda Kota Bengkulu Abstrak. Sumber Belajar Dan Alat Permainan Untuk Pendidikan Anak Usia Dini, 2(1), 229-241. https://doi.org/http://dx.doi.org/10.29300/alfitrah.v3i2.3788

Pentury, H. J. (2018). Pengembangan Literasi Guru PAUD Melalui Bahan Ajar Membaca, Menulis dan Berhitung Di Kecamatan Limo dan Cinere. DIKEMAS (Jurnal Pengabdian Kepada Masyarakat), 1(1), 14-21. https://doi.org/10.32486/jd.v1i1.167

Septiarti, S. W. (2017). Sosiologi Dan Antropologi Pendidikan. Yogyakarta: UNY Press.

Sugiyono. (2013). Metode Penelitian Kualitatif dan $R \& D$. Bandung: Alfabeta. 
Sujiono. (2009). Konsep Dasar Pendidikan Anak Usia Dini. Jakarta: Indeks.

Syam, M. N. (1984). Filsafat pendidikan dan dasar filsafat pendidikan pancasila. Surabaya: Usaha Nasional.

Syukur, A. (2010). Pengantar Studi Islam. Semarang: Pustaka Rizki.

Tafsir, A. (2005). Ilmu Pendidikan Dalam Perspektif Islam. Bandung: PT Remaja Rosdakarya.

Tatminingsih, S. (2019). Alternatif Stimulasi Kemampuan Kognitif melalui Penerapan Model Pembelajaran Berbasis Permainan Komprehensif. Jurnal Obsesi : Jurnal Pendidikan Anak Usia Dini, 3(1), 183. https://doi.org/10.31004/obsesi.v3i1.130

Wahyuni, F. (2019). Pendidikan Anak Usia Dini (PAUD) Holistik Integratif. Qalamuna, 11(2), 6172. https://doi.org/https://doi.org/10.5281/zenodo.3559281

Wartini, A. (2016). Tafsir Tematik Kemenag: Studi Al-Qur'an Dan Pendidikan Anak Usia Dini. Maghza, 1(2), 1. https://doi.org/10.24090/mza.v1i2.2016.pp1-20

Yuliani, N. (2011). Konsep Dasar Pendidikan Anak Usia Dini. Jakarta: Indeks.

Yulyani, Y., Kazumaretha, T., Arisanti, Y., Fitria, Y., \& Desyandri, D. (2020). Implementasi Kompetensi Pedagogik Guru Dalam Pembelajaran Tematik Di Sekolah Dasar. School $\begin{array}{llllll}\text { Education Journal Pip } & \text { Unimed, } & 10(2), & 184 .\end{array}$ https://doi.org/10.24114/sejpgsd.v10i2.18545

Zahrudin. (2004). Pengantar Studi Akhlak. Jakarta: Raja Grafindo Persada.

Zainal Arifin, Yaqin, M. A. (2019). Kompetensi Pedagogik Pendidik Dalam Perspektif Al-Qur'an. $A l$ Qodiri: Jurnal Pendidikan, Sosial dan Keagamaan, 17(2), 416-427. https://doi.org/https://doi.org/10.1234/al\%20qodiri.v17i2.3844 